\title{
Differential synovial tissue biomarkers among psoriatic arthritis and rheumatoid factor/anti-citrulline antibody-negative rheumatoid arthritis
}

Stefano Alivernini ${ }^{1,2}$, Dario Bruno ${ }^{2}$, Barbara Tolusso ${ }^{1}$, Laura Bui ${ }^{3}$, Luca Petricca ${ }^{1}$, Maria Rita Gigante ${ }^{1}$, Domenico Birra², Anna Laura Fedele1, Giusy Peluso', Francesco Federico ${ }^{3,4}$, Gianfranco Ferraccioli² and Elisa Gremese ${ }^{1,2^{*}}$ (1)

\begin{abstract}
Background: Differential diagnosis among psoriatic arthritis (PSA) and seronegative rheumatoid arthritis (Ab ${ }^{\text {neg }}$ RA) can be challenging particularly in the clinical setting of peripheral phenotype and autoantibodies seronegativity. The aim of the study was to identify synovial tissue (ST) biomarkers differentially expressed in PSA and Ab ${ }^{\text {neg }}$ RA and test their predictive value of therapeutic response.

Methods: Thirty-four PsA patients [12 DMARD naive and 22 non-responder to methotrexate (MTX-IR)] with peripheral joint involvement and $55 \mathrm{Ab}^{\text {neg }} \mathrm{RA}$ (27 DMARD naive and 28 MTX-IR) underwent US-guided ST biopsy and immunohistochemistry $(\mathrm{IHC})$ for $\mathrm{CD}_{6} 8^{+}, \mathrm{CD}^{+}, \mathrm{CD}_{2} \mathrm{O}^{+}, \mathrm{CD} 21^{+}, \mathrm{CD} 117^{+}$, and $\mathrm{CD} 138^{+}$cells. After study entry, each DMARD-naive patient started MTX therapy and was followed in an outpatient setting for at least 6 months to define the achievement of Minimal Disease Activity (PsA) and DAS remission (Ab ${ }^{\text {neg }}$ RA) status respectively. Each IR-MTX patient was treated according to EULAR recommendations.

Results: At study entry, IHC analysis revealed that PsA patients had comparable levels of lining and sublining $\mathrm{CD}_{6}{ }^{+}$and sublining $\mathrm{CD}_{21} 1^{+}, \mathrm{CD}_{2} \mathrm{O}^{+}$, and $\mathrm{CD}^{+}$cells than $\mathrm{Ab}^{\text {neg }} \mathrm{RA}$, despite the therapeutic regimen. Moreover, regardless of the therapeutic scheme, PsA patients showed higher IHC score of CD $117^{+}$cells $(p=0$. 0004 and $p=0.0005$ for naive and MTX-IR patients respectively) compared to Ab ${ }^{\text {neg }}$ RA patients. Conversely, $A b^{\text {neg }}$ RA patients showed higher $I H C$ score of $C D 138^{+}$cells, irrespective to the therapeutic scheme $(p=0.04$ and $p=0.002$ for naive and MTX-IR patients respectively). Analyzing the response rate to the therapeutic scheme, naive PsA patients reaching MDA status at 6 months follow-up, showed, at the study entry, lower IHC score of $\mathrm{CD}^{+}$cells compared to PSA patients not reaching this outcome $(p=0.02)$; conversely, naive $A b^{\text {neg }}$ RA patients reaching DAS remission status at 6 months follow-up, showed, at the study entry, lower IHC score of sublining CD68 ${ }^{+}$cells compared to $A b^{\text {neg }}$ RA patients not reaching this outcome $(p<0.001)$. Conclusions: $C D 117^{+}$and $C D 138^{+}$cells are differentially distributed among PSA and Ab neg RA. Histological analysis of ST may help to solve the clinical overlap between the two diseases and provides prognostic data about the therapy success.
\end{abstract}

Keywords: Psoriatic arthritis, Rheumatoid arthritis, Synovial tissue, Autoantibodies, Response to therapy

\footnotetext{
* Correspondence: elisa.gremese@unicatt.it

${ }^{1}$ Division of Rheumatology, Fondazione Policlinico Universitario A. Gemelli IRCCS, Rome, Italy

${ }^{2}$ Institute of Rheumatology, Università Cattolica del Sacro Cuore, Rome, Italy

Full list of author information is available at the end of the article
}

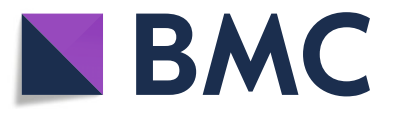

(c) The Author(s). 2019 Open Access This article is distributed under the terms of the Creative Commons Attribution 4.0 International License (http://creativecommons.org/licenses/by/4.0/), which permits unrestricted use, distribution, and reproduction in any medium, provided you give appropriate credit to the original author(s) and the source, provide a link to the Creative Commons license, and indicate if changes were made. The Creative Commons Public Domain Dedication waiver (http://creativecommons.org/publicdomain/zero/1.0/) applies to the data made available in this article, unless otherwise stated. 


\section{Introduction}

Psoriatic arthritis (PsA) is a chronic inflammatory disease characterized by remarkable heterogeneity of clinical presentation, including peripheral arthritis, axial involvement, enthesitis, dactylitis, nail dystrophy, uveitis, and osteitis, in addition to associated comorbidities such as cardiovascular disease, metabolic syndrome, and mood disorders [1, 2]. Most patients with PsA present with oligoarticular or polyarticular arthritis and can be differentiated from patients with rheumatoid arthritis (RA), the most common inflammatory joint disease, by specific non-articular clinical features being present, as well as the infrequent seropositivity for rheumatoid factor (RF) and anti-citrullinated peptide antibody (ACPA). These clinical features include an asymmetric distribution of the inflamed joints, the sacroiliitis or spinal involvement, the typical involvement of the distal interphalangeal joint (DIP), and the extra-articular manifestations [1]. However, in clinical practice, the differential diagnosis among PsA and RA can be challenging, particularly if the peripheral phenotype is present and RF and ACPA are negative. In recent years, there have been a number of advances made in synovial tissue biopsy techniques in patients with inflammatory joint diseases [3]. However, despite many research groups have focused on the analysis of possible differential biomarkers among PsA and RA, no studies have been performed considering a direct comparison between PsA with a RF/ACPA seronegative $\left(\mathrm{Ab}^{\mathrm{neg}}\right) \mathrm{RA}$ cohort $[4,5]$.

Based on that, the aims of the study were (i) to assess whether the histological characteristics of synovial tissue of PsA patients with peripheral arthritis phenotype compared to seronegative RA patients could differ in different disease phases and (ii) to evaluate possible predictive synovial biomarkers associated with treatment response in PsA and seronegative RA patients at disease onset and after c-DMARD failure.

\section{Patients and methods}

\section{Patient enrollment}

Eighty-nine patients were enrolled in the study [34 oligo-polyarticular PsA patients (12 naïve and 22 inadequately responder to methotrexate (MTX-IR) respectively) and 55 RA patients (27 naïve and 28 MTX-IR respectively)] fulfilling the classification criteria for PsA or RA [6, 7]. At baseline, demographical, clinical, and inflammatory parameters were collected for each patient. All RA patients were confirmed as being seronegative $\left(\mathrm{Ab}^{\text {neg }}\right)$ for IgA- and IgM-RF (Orgentec Diagnostika, Bouty, UK) and ACPA (Axis Shield Diagnostics, Bouty, UK) using commercial ELISA at study entry. Each naïve PsA and $A b^{\text {neg }}$ RA patient was then treated with methotrexate (up to $20 \mathrm{mg} /$ week) and followed every 3 months for at least 6 months to assess the rate of achievement of Minimal Disease Activity (MDA) or DAS remission for PsA and $A b^{\text {neg }} \mathrm{RA}$ patients respectively
$[8,9]$. MTX-IR PsA and Ab ${ }^{\text {neg }}$ RA patients were treated according to the current recommendations $[10,11]$. The study protocol was approved by the local Ethical Committee, and all subjects provided signed informed consent.

\section{Immunohistochemistry for CD68, CD21, CD3, CD20, CD138, CD117, and CD31 on synovial tissue} At study entry, each PsA and $A b^{\text {neg }} R A$ patient underwent ultrasound-guided synovial tissue biopsy of the knee. Joint inflammatory activity was tested for each patient using power Doppler as previously described [12]. Each tissue was tested through immunohistochemistry for the presence of CD68 (macrophages), CD21 (follicular dendritic cells), CD3 (T lymphocytes), CD20 (B lymphocytes), and CD31 (endothelial cells) staining following the already published protocol [12]. Other tissue sections were stained for plasma cell and mast cell detection, using CD138 mouse antihuman monoclonal antibody (clone MI15) or CD117 mouse antihuman monoclonal antibody (clone EP10) (all from Leica Biosystem, Newcastle, UK) by immunostainer BOND MAX III (Leica). Slides were examined by two independent evaluators using a light microscope (Leica DM 2000), and all tissues were evaluated using a numerical score based on the number of $\mathrm{CD}^{+} 8^{+}, \mathrm{CD} 21^{+}, \mathrm{CD}^{+}, \mathrm{CD}_{20}{ }^{+}, \mathrm{CD}_{117^{+}}$, and $\mathrm{CD} 138^{+}$cells (two different fields in each section), with a score of 0 indicating no positive cells, 1 indicating $<10 \%$ positive cells, 2 indicating $10-50 \%$ positive cells, and 3 indicating $>50 \%$ positive cells. $\mathrm{CD} 1^{+}$vessel count was done as mean of the values from three different fields in each section [12]. The inter-rater agreement coefficient was assessed for each single IHC marker (see Additional file 2: Table S1).

\section{Statistical analysis}

Statistical analysis was performed using SPSS V. 20.0 (SPSS. Chicago, IL, USA) and Prism software (GraphPad, San Diego, CA, USA). Categorical and quantitative variables were described as frequencies, percentage, and mean \pm SD. Data on demographic and clinical features were compared between patients by the non-parametric Mann-Whitney $U$ test or $\chi^{2}$ test, as appropriate. Spearman's rank correlation test was used for correlation in all analyses. ROC analysis was performed to identify the best cut-off value for IHC scores associated with the highest rate of MDA or DAS remission achievement in PsA and $\mathrm{Ab}^{\text {neg }} \mathrm{RA}$ patients respectively. A value of $p \leq 0.05$ was considered statistically significant.

\section{Results}

Demographic and clinical characteristics of the enrolled study cohorts

Demographic and clinical characteristics of PsA and $A b^{\text {neg }}$ RA cohorts (naïve and MTX-IR respectively) enrolled in the study are summarized in Table 1 . 
Table 1 Demographical, clinical, and immunological characteristics of the study cohorts

\begin{tabular}{|c|c|c|c|c|c|c|c|c|}
\hline & \multicolumn{2}{|l|}{$\operatorname{PSA}(n=34)$} & \multirow[t]{2}{*}{$p$} & \multicolumn{2}{|c|}{$\mathrm{Ab}^{\text {neg }} \mathrm{RA}(n=55)$} & \multirow[t]{2}{*}{$p^{1}$} & \multirow[t]{2}{*}{$p^{2}$} & \multirow[t]{2}{*}{$p^{3}$} \\
\hline & Naive $(n=12)$ & MTX-IR $(n=22)$ & & Naive $(n=27)$ & $\operatorname{MTX}-\operatorname{IR}(n=28)$ & & & \\
\hline Age, years (mean $\pm S D$ ) & $54.75 \pm 17.18$ & $60.18 \pm 9.81$ & 0.47 & $52.41 \pm 17.70$ & $58.36 \pm 16.58$ & 0.16 & 0.68 & 0.77 \\
\hline Female, $n(\%)$ & $4(33.3)$ & $14(63.6)$ & 0.10 & $23(85.2)$ & $23(82.1)$ & 0.76 & 0.001 & 0.14 \\
\hline Disease duration, years (mean $\pm S D$ ) & $0.80 \pm 0.24$ & $5.83 \pm 3.68$ & $<0.001$ & $0.84 \pm 0.95$ & $5.68 \pm 5.28$ & 0.002 & 0.44 & 0.49 \\
\hline DAS44 (mean \pm SD) & $3.00 \pm 0.42$ & $3.34 \pm 0.91$ & 0.34 & $3.37 \pm 1.05$ & $3.22 \pm 0.79$ & 0.71 & 0.52 & 0.81 \\
\hline DAPSA (mean \pm SD) & $22.55 \pm 8.38$ & $28.04 \pm 10.14$ & 0.10 & - & - & - & - & - \\
\hline $\mathrm{SJC}($ mean $\pm \mathrm{SD})$ & $4.00 \pm 2.67$ & $6.43 \pm 5.69$ & 0.35 & $8.22 \pm 7.95$ & $7.15 \pm 5.53$ & 0.93 & 0.18 & 0.54 \\
\hline TJC (mean \pm SD) & $5.00 \pm 3.16$ & $7.00 \pm 6.13$ & 0.66 & $8.22 \pm 7.86$ & $8.44 \pm 5.46$ & 0.33 & 0.51 & 0.24 \\
\hline $\mathrm{ESR}, \mathrm{mm} / 1 \mathrm{st}$ hour (mean $\pm \mathrm{SD}$ ) & $29.60 \pm 36.94$ & $29.10 \pm 19.59$ & 0.44 & $44.00 \pm 25.40$ & $37.04 \pm 27.25$ & 0.19 & 0.03 & 0.44 \\
\hline $\mathrm{CRP}, \mathrm{mg} / \mathrm{l}(\mathrm{mean} \pm \mathrm{SD})$ & $16.70 \pm 29.16$ & $18.11 \pm 23.41$ & 0.70 & $16.99 \pm 19.43$ & $16.77 \pm 24.23$ & 0.77 & 0.72 & 1.00 \\
\hline Ab positivity, $n(\%)$ & $0(0.0)$ & $0(0.0)$ & 1.00 & $0(0.0)$ & $0(0.0)$ & 1.00 & 1.00 & 1.00 \\
\hline
\end{tabular}

Data presented in italics have $p<0.05$

PSA psoriatic arthritis, RA rheumatoid arthritis, Ab autoantibody, DAS Disease Activity Score, DAPSA Disease Activity in PSoriatic Arthritis, SJC swollen joint count, $T J C$ tender joint count, ESR erythrocyte sedimentation rate, CRP C-reactive protein, SD standard deviation, MTX-IR methotrexate inadequately responder, $p$ naive PsA vs MTX-IR PsA, $p^{7}$ naive $A b^{\text {neg }}$ RA vs MTX-IR A ${ }^{\text {neg }}$ RA, $p^{2}$ naive PsA vs naive $A b^{\text {neg }} R A, p^{3}$ MTX-IR PsA vs MTX-IR A $b^{\text {neg }} R A$

Comparing the different study cohorts, there were no significant differences according to age and gender $(p>$ 0.05). PsA and $A b^{\text {neg }} R A$ patients naïve to treatment showed significant shorter disease duration $(0.80 \pm 0.24$ years for naive PsA and $0.84 \pm 0.95 \mathrm{Ab}^{\text {neg }} \mathrm{RA}$ patients respectively) compared to MTX-IR PsA and $A b^{\text {neg }}$ RA patients $(5.83 \pm 3.68$ years for MTX-IR PsA, $p<0.001$; $5.68 \pm 5.28$ for MTX-IR Ab ${ }^{\text {neg }}$ RA patients, $p=0.002$ respectively). Considering the clinical parameters, there were no significant differences comparing PsA and $\mathrm{Ab}^{\text {neg }}$ RA patients based on swollen and tender joint counts or Disease Activity Scores in naïve and in MTX-IR subgroups (Table 1). However, considering inflammatory markers, ESR plasma levels were significantly higher in naïve $\mathrm{Ab}^{\text {neg }} \mathrm{RA}$ patients $(44.00 \pm 25.40 \mathrm{~mm} /$ first hour $)$ than MTX-IR $A b^{\text {neg }}$ RA patients $(29.60 \pm 36.94 \mathrm{~mm} /$ first hour; $p=0.03$ ), whereas no differences were found for CRP plasma levels comparing naïve and MTX-IR PsA subgroups (Table 1).

\section{PsA and $A b^{\text {neg }} R A$ show similar histological features in terms of synovial resident $\mathrm{CD}_{68}{ }^{+}, \mathrm{CD}_{2} 1^{+}$, and $\mathrm{CD}^{+}$cells and microanatomical organization}

Each enrolled patient underwent US-guided ST biopsy, and $\mathrm{IHC}$ for $\mathrm{CD}_{6} 8^{+}, \mathrm{CD} 21^{+}, \mathrm{CD} 20^{+}$, and $\mathrm{CD}^{+}$was performed. PsA patients showed similar $\mathrm{IHC} \mathrm{CD}^{+} 8^{+}$cell score in the lining $(1.95 \pm 0.90)$ and sublining $(1.81 \pm 0.95)$ compared to $\mathrm{Ab}^{\text {neg }} \mathrm{RA}$ patients $(1.96 \pm 0.75$ for lining $\mathrm{CD}^{+} 8^{+}$cells, $p=0.94 ; 1.43 \pm 0.76$ for sublining $\mathrm{CD}^{+} 8^{+}$ cells, $p=0.11$ respectively) regardless of the treatment scheme (Fig. 1a-d). Furthermore, IHC analysis revealed that PsA and $\mathrm{Ab}^{\text {neg }} \mathrm{RA}$ patients had comparable levels of $\mathrm{CD} 21^{+}$cells $(0.72 \pm 0.79$ vs $0.60 \pm 0.95 ; p=0.18$ respectively) regardless of the treatment scheme (Fig. 1a-d).
Stratifying the study cohorts according to the treatment scheme, naïve PsA showed similar IHC scores for lining $(2.00 \pm 0.85)$ and sublining $\mathrm{CD}^{+} 8^{+}$cells $(1.71 \pm$ $0.96)$ compared to naïve $\mathrm{Ab}^{\text {neg }} \mathrm{RA}$ patients $(1.96 \pm 0.79$ for lining $\mathrm{CD}^{+} 8^{+}$cells, $p=1.00 ; 1.44 \pm 0.80$ for sublining $\mathrm{CD}^{+} 8^{+}$cells, $p=0.39$ respectively). Moreover, naïve PsA showed similar IHC scores for $\mathrm{CD} 21^{+}$cells $(0.75 \pm 0.94)$ compared to naïve $\mathrm{Ab}^{\text {neg }} \mathrm{RA}$ patients $(0.52 \pm 0.91 ; p=$ 0.43) (Fig. 1g), showing a direct correlation between ESR plasma levels and lining $\mathrm{CD}^{+} 8^{+}$cells IHC score $(r=0.66$; $p=0.04)$. Similarly, MTX-IR PsA patients showed comparable IHC scores for lining $(1.92 \pm 0.95)$ and sublining $\mathrm{CD}^{+} 8^{+}$cells $(1.86 \pm 0.96)$ than MTX-IR $\mathrm{Ab}^{\text {neg }} \mathrm{RA}$ patients $\left(2.00 \pm 0.72\right.$ for lining $\mathrm{CD}^{+} 8^{+}$cells, $p=0.79 ; 1.46 \pm$ 0.78 for sublining $\mathrm{CD}^{+} 8^{+}$cells, $p=0.25$ ) (Fig. $1 \mathrm{e}-\mathrm{h}$ ). Finally, MTX-IR PsA showed similar IHC scores for CD21 ${ }^{+}$cells $(0.71 \pm 0.73)$ compared to MTX-IR $\mathrm{Ab}^{\text {neg }}$ RA patients $(0.68 \pm 1.00 ; p=0.91)$ (Fig. 1g).

Analyzing the microanatomical organization of the synovial tissue infiltrates, 15 (44.1\%) PsA patients compared to 24 (43.6\%, $p=0.51) \mathrm{Ab}^{\text {neg }}$ RA patients showed follicular synovitis regardless of the treatment regimen. Moreover, there was no difference in the rate of follicular synovitis stratifying patients according to the therapeutic regimen $(41.7 \%$ of naïve PsA patients with follicular synovitis compared to $45.5 \%$ of MTX-IR PsA patients with similar synovitis pattern, $p=0.79 ; 44.4 \%$ of naive $A b^{\text {neg }} R A$ patients with follicular synovitis compared to $42.8 \%$ of MTX-IR $A^{\text {neg }}$ RA patients with similar synovitis pattern, $p=0.51$ ).

$\mathrm{CD} 20 \mathrm{IHC}$ revealed that PsA and $\mathrm{Ab}^{\text {neg }} \mathrm{RA}$ patients had similar levels of $\mathrm{CD}_{2} 0^{+}$cells $(1.08 \pm 0.73$ in PsA vs $1.44 \pm 0.89$ in $\mathrm{Ab}^{\text {neg }} \mathrm{RA}, p=0.07$ ) (Fig. $2 \mathrm{a}-\mathrm{d}$ ) and after stratification based on the treatment regimen, PsA 


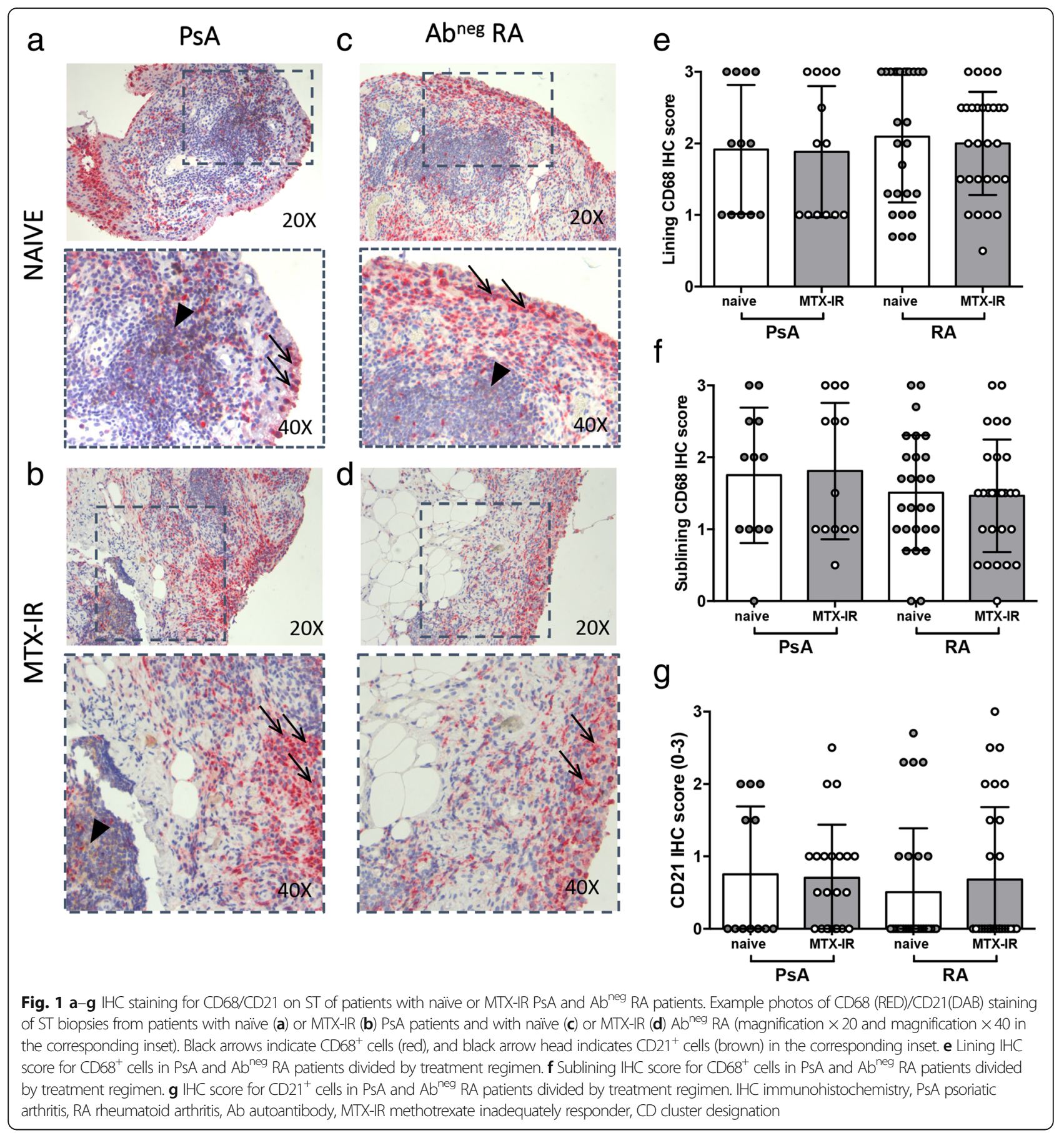

patients showed similar $\mathrm{IHC} \mathrm{CD}^{+} 0^{+}$cell score than $\mathrm{Ab}^{\text {neg }} \mathrm{RA}(1.00 \pm 0.85$ in naive PsA vs $1.44 \pm 0.92$ in naive $\mathrm{Ab}^{\text {neg }} \mathrm{RA}, p=0.16 ; 1.14 \pm 0.67$ in MTX-IR PsA vs $1.45 \pm 0.87$ MTX-IR $\mathrm{Ab}^{\text {neg }} \mathrm{RA}, p=0.18$ ) (Fig. 2e).

Analyzing synovial $\mathrm{CD}^{+}$cell distribution, IHC showed that PsA and $A b^{\text {neg }} \mathrm{RA}$ patients had similar levels of synovial $\mathrm{CD}^{+}$cells $(1.71 \pm 0.86$ in PsA and $1.54 \pm 0.86$ in $\mathrm{Ab}^{\text {neg }} \mathrm{RA} ; p=0.45$ respectively) (Fig. $2 \mathrm{a}-\mathrm{d}$ ). Moreover, PsA and $A b^{\text {neg }} R A$ patients did not differ in terms of synovial $\mathrm{CD}^{+}$cells stratifying patients based on the treatment scheme $(1.45 \pm 0.83$ in naive PsA vs $1.57 \pm$ 0.88 in naïve $\mathrm{Ab}^{\text {neg }} \mathrm{RA}, p=0.70 ; 1.84 \pm 0.86$ in MTX-IR PsA vs $1.52 \pm 0.87$ MTX-IR Ab ${ }^{\text {neg }}$ RA, $p=0.19$ ) (Fig. 2f).

Synovial $\mathrm{CD} 117^{+}$and $\mathrm{CD} 138^{+}$cells are differentially distributed in PsA and $A b^{\text {neg }}$ RA patients

CD117 IHC showed that PsA patients are characterized by higher IHC scores for $\mathrm{CD}_{117^{+}}$cells $(1.25 \pm 0.61)$ 


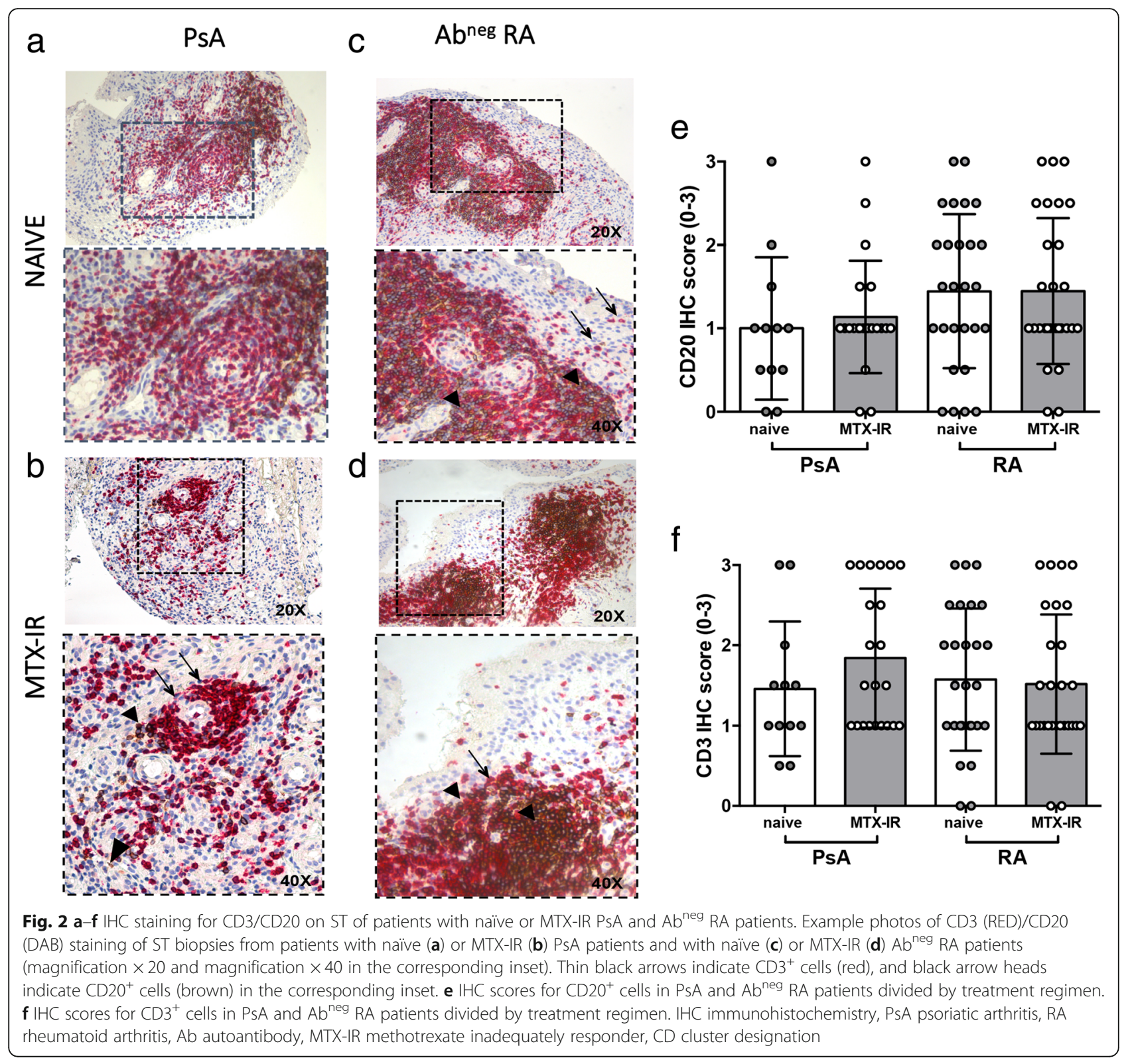

compared to $\mathrm{Ab}^{\text {neg }} \mathrm{RA}$ patients $(0.62 \pm 0.46, p<0.001)$ regardless of the treatment scheme (Fig. 3a-d). Interestingly, stratifying the study cohorts according to the treatment scheme, naïve PsA patients showed higher $\mathrm{CD} 117^{+}$cell $\mathrm{IHC}$ scores $(1.29 \pm 0.65)$ compared to naïve $\mathrm{Ab}^{\text {neg }} \mathrm{RA}$ patients $(0.59 \pm 0.44 ; p=0.0004)$. Similarly, MTX-IR PsA patients showed higher $\mathrm{CD} 117^{+} \mathrm{IHC}$ score $(1.23 \pm 0.61)$ compared to MTX-IR Ab ${ }^{\text {neg }} \mathrm{RA}$ patients $(0.64 \pm 0.48, p=0.001)$ (Fig. 3e).

Conversely, analyzing the distribution of $\mathrm{CD} 138^{+}$cells within the synovial tissue, $\mathrm{Ab}^{\text {neg }} \mathrm{RA}$ patients showed higher IHC scores for CD138 ${ }^{+}$cells $(1.58 \pm 1.09)$ compared to PsA patients $(0.72 \pm 0.71 ; p<0.001)$ independently of the treatment scheme (Fig. 3f-i). Considering the different study population subgroups, naive $A b^{\text {neg }} \mathrm{RA}$ patients were characterized by higher $\mathrm{CD} 138^{+}$cell IHC score $(1.65 \pm$ 1.00) compared to naive PsA patients $(0.96 \pm 0.84 ; p=0.04)$. Similarly, MTX-IR Ab ${ }^{\text {neg }}$ RA patients had higher CD138 ${ }^{+}$ cell IHC score $(1.51 \pm 1.19)$ compared to MTX-IR PsA patients $(0.59 \pm 0.61, p=0.002)$ (Fig. 3j). As shown in Fig. 3k, the combination of low IHC score for $\mathrm{CD} 117^{+}$(IHC score $=1$ ) and high IHC score for CD138 $8^{+}$cells (IHC score $=3$ ) significantly differentiates PsA than $\mathrm{Ab}^{\text {neg }} \mathrm{RA}$ synovitis [OR (95\% CI), 34.04 (1.535-2.398); $p=0.0002]$.

Synovial $C D 31^{+}$vessel count is associated with the disease phase in PsA and $A b^{\text {neg }}$ RA patients

To assess the microvasculature at the synovial tissue level, each tissue was tested for the presence of CD31 blood vessels. As shown in Fig. 4a-e, naïve PsA patients 

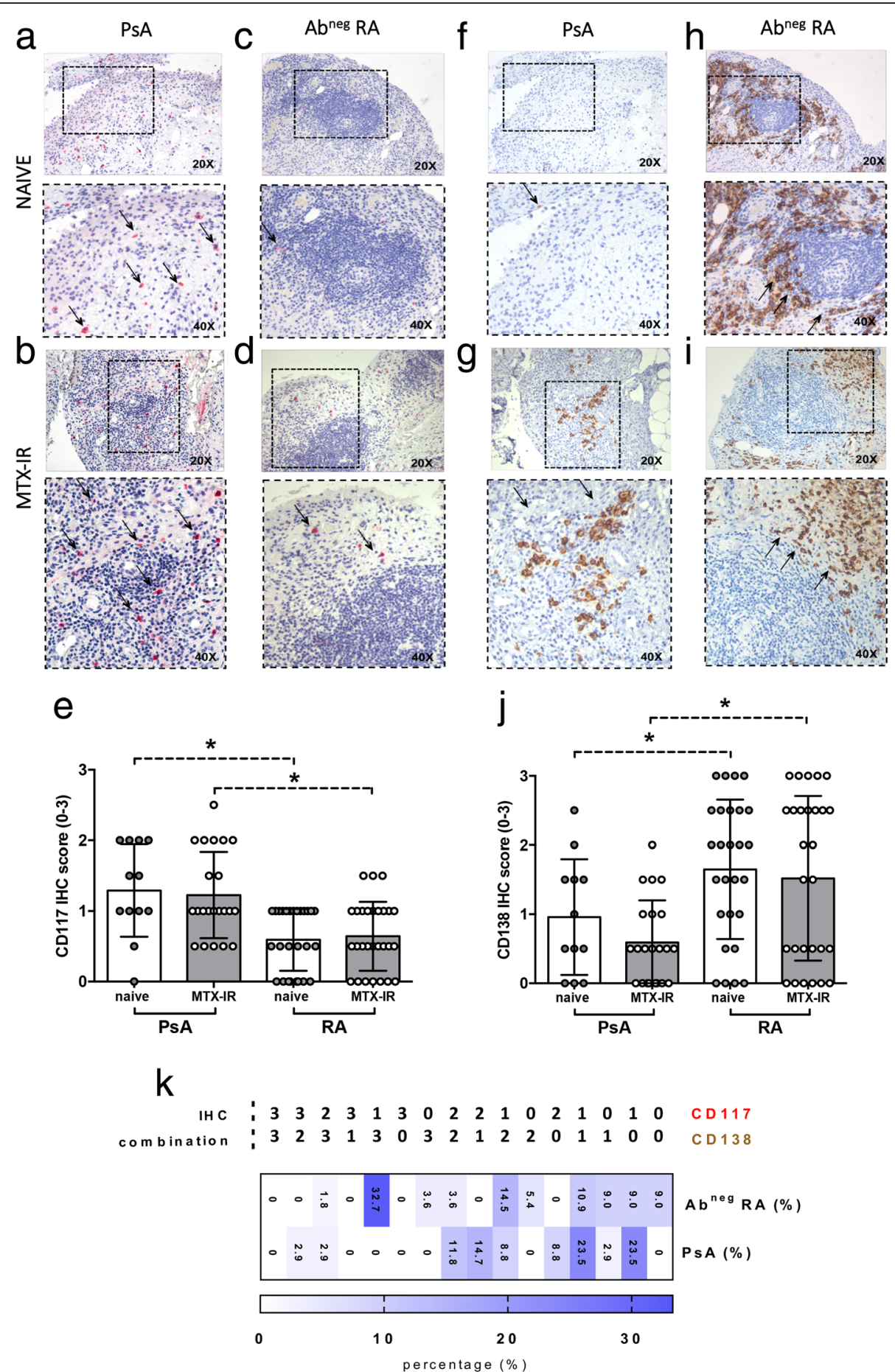

Fig. 3 a-k $\mathbb{H C}$ staining for CD117 and CD138 on ST of patients with naive or MTX-IR PSA and Ab ${ }^{\text {neg }}$ RA patients. Example photos of CD117 (RED) staining of ST biopsies from patients with naïv (a) or MTX-IR (b) PsA and with naive (c) or MTX-IR (d) Ab ${ }^{\text {neg }}$ RA (magnification $\times 20$ and magnification $\times 40$ in the corresponding inset). Thin black arrows indicate $C D 117^{+}$cells (red) in the corresponding inset. e $\| \mathrm{HC}$ scores for CD $117^{+}$cells in PsA and Ab ${ }^{\text {neg }} \mathrm{RA}$ patients divided by treatment regimen; ${ }^{*} p=0.0004$, naïve PsA vs naiive $A b^{\text {neg }}$ RA patients; ${ }^{*} p=0.0005$, MTX-IR PSA vs MTX-IR Ab ${ }^{\text {neg }}$ RA patients. Example photos of CD138 (DAB) staining of ST biopsies from patients with naïve $(\mathbf{f})$ or MTX-IR (g) PSA and with naïve (h) or MTX-IR (i) Ab ${ }^{\text {neg }}$ RA (magnification $\times 20$ and magnification $\times 40$ in the corresponding inset). Thin black arrows indicate CD138 $8^{+}$cells (brown) in the corresponding inset. $\mathbf{j} \| \mathrm{HC}$ scores for CD138 ${ }^{+}$cells in PsA and $A b^{\text {neg }} R A$ patients divided by treatment regimen; ${ }^{*} p=0.04$, naive PsA vs naive A $b^{\text {neg }} R A$ patients; ${ }^{*} p=0.002$, MTX-IR PsA vs MTX-IR A $b^{\text {neg }}$ RA patients. k Rate of distribution of CD117/CD138 IHC combination differentially distributed among PsA and Ab ${ }^{\text {neg }}$ RA patients. IHC immunohistochemistry, PsA psoriatic arthritis, RA rheumatoid arthritis, Ab autoantibody, MTX-IR methotrexate inadequately responder, CD cluster designation 


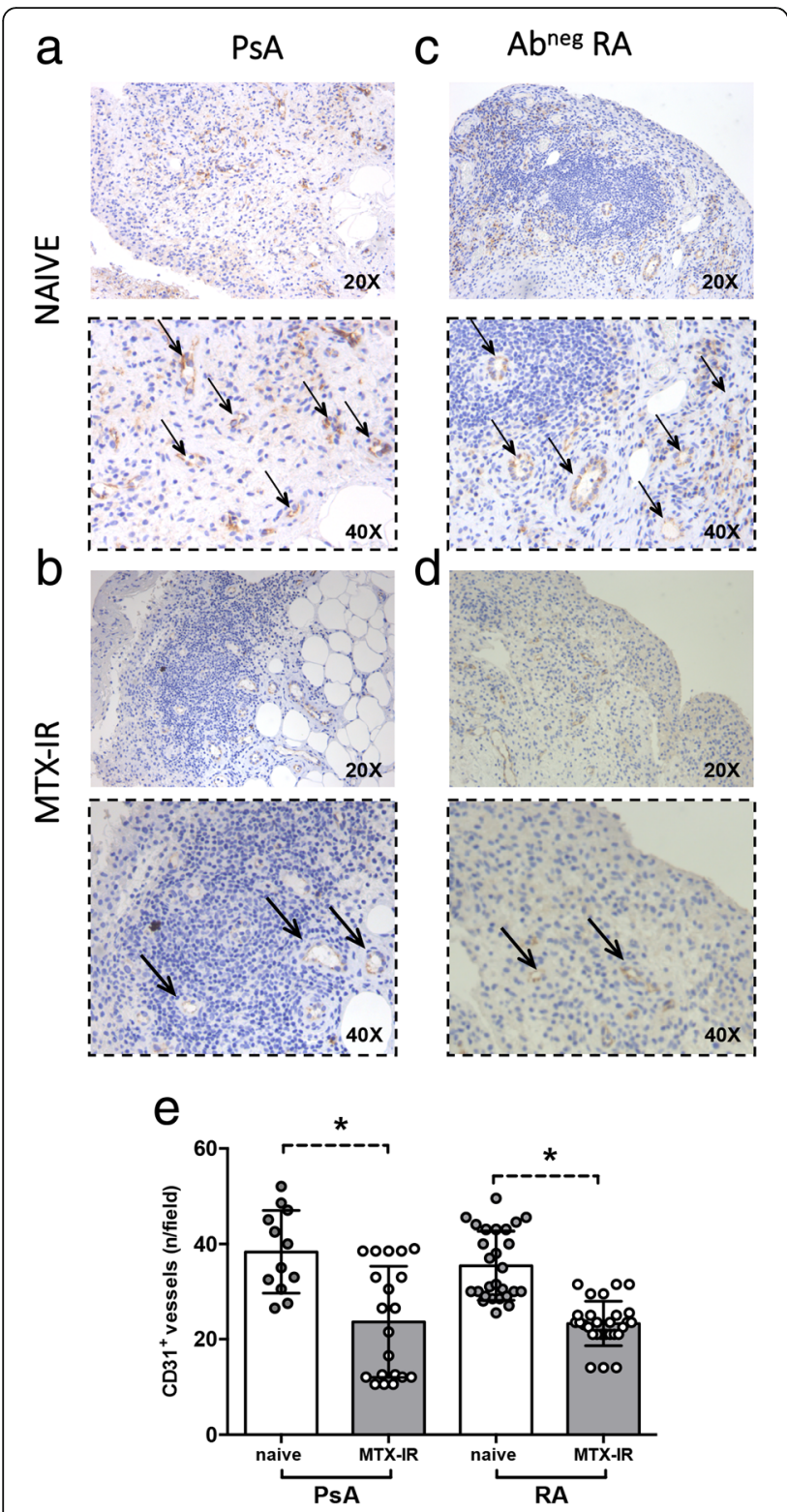

Fig. 4 a-e $\mathrm{HC}$ staining for $C D 31$ on ST of patients with naive or MTX-IR PsA and Ab ${ }^{\text {neg }}$ RA patients. Example photos of CD31 (DAB) staining of ST biopsies from patients with naïve (a) or MTX-IR (b) PSA and with naïve (c) or MTX-IR (d) $A b^{\text {neg }}$ RA (magnification $\times 20$ and magnification $\times 40$ in the corresponding inset). Thin black arrows indicate $\mathrm{CD}_{3} 1^{+}$vessels (brown) in the corresponding inset. e Synovial $\mathrm{CD} 31^{+}$vessel count in PsA and $\mathrm{Ab}{ }^{\text {neg }}$ RA patients divided by treatment regimen; ${ }^{*} p=0.01$, naiive vs MTX-IR PSA patients; ${ }^{*} p<0.001$, naïve vs MTX-IR $A b^{\text {neg }}$ RA patients. IHC immunohistochemistry, PsA psoriatic arthritis, RA rheumatoid arthritis, Ab autoantibody, MTX-IR methotrexate inadequately responder, $\mathrm{CD}$ cluster designation

showed higher number of synovial CD31 ${ }^{+}$vessels $(36.63$ $\pm 11.02)$ compared to MTX-IR PsA patients $(23.65 \pm$ 11.67; $p=0.01)$. Similarly, naïve $A b^{\text {neg }} \mathrm{RA}$ patients showed a higher number of synovial $\mathrm{CD}^{+} 1^{+}$vessels $(35.43 \pm 7.23)$ than MTX-IR Ab ${ }^{\text {neg }}$ RA patients $(22.14 \pm$ 5.32; $p<0.001)$. No significant differences in terms of
$\mathrm{CD} 1^{+}$vessel count were found comparing PsA and $\mathrm{Ab}^{\text {neg }} \mathrm{RA}$ patients stratified based on the same treatment category (Fig. 4e).

\section{Baseline synovial $\mathrm{CD}^{+}$and $\mathrm{CD}^{+} 8^{+}$cell IHC scores are associated with Minimal Disease Activity and remission achievement in $\mathrm{PsA}$ and $A b^{\text {neg }} \mathrm{RA}$ patients naïve to treatment respectively}

After study enrollment, each naïve patient started methotrexate treatment and was followed for at least 6 months on outpatient setting and treatment response rate was recorded at each clinical assessment (MDA for PsA and DAS remission for $A b^{\text {neg }} R A$ patients respectively). After 6 months follow-up from methotrexate beginning, 6 (50.0\%) PsA patients achieved MDA, while 11 (40.7\%) $\mathrm{Ab}^{\text {neg }} \mathrm{RA}$ patients achieved DAS remission. As shown in Table 2, naïve PsA patients who reached the MDA status at 6 months follow-up had lower $\mathrm{CD}^{+}$cell IHC score $(0.91 \pm 0.33)$ before methotrexate beginning, compared to naïve PsA patients who did not achieve the clinical endpoint at 6 months (1.99 $\pm 0.84 ; p=0.02)$. Conversely, naïve $\mathrm{Ab}^{\text {neg }} \mathrm{RA}$ patients who reached the DAS remission status at 6 months follow-up had lower sublining $\mathrm{CD}^{+} 8^{+}$cell IHC score $(0.92 \pm$ 0.58 ) before methotrexate beginning, compared to naïve $\mathrm{Ab}^{\text {neg }} \mathrm{RA}$ patients who did not achieved the clinical endpoint at 6 months $(2.13 \pm 0.55 ; p<0.001)$ (Table 2). To define the best cut-off value for $\mathrm{CD}^{+}$cell scores and $\mathrm{CD} 68^{+}$ cell sublining scores in naive PsA and $\mathrm{Ab}^{\text {neg }} \mathrm{RA}$ respectively, ROC analysis was performed for each parameter (Additional file 1: Figure S1a-b). In particular, naive PsA patients who reached a MDA status after 6 months follow-up had more likely baseline $\mathrm{CD}^{+}$cell scores $<1.25$ (83.3\%) than naive PsA patients who did not reach MDA status $(16.7 \%, p$ $=0.02$ ). Moreover, naive $\mathrm{Ab}^{\text {neg }} \mathrm{RA}$ patients who reached DAS remission after 6 months follow-up had more likely baseline $\mathrm{CD}^{+} 8^{+}$cell sublining scores $<2.25(65.0 \%)$ than naive $\mathrm{Ab}^{\text {neg }} \mathrm{RA}$ patients who did not reach DAS remission $(0.0 \%, p=0.03)$. In relation to MTX-IR patients, there was no significant difference in MDA and DAS remission status achievement in PsA and $\mathrm{Ab}^{\text {neg }} \mathrm{RA}$ patients respectively, even stratifying patients based on the therapeutic strategy after MTX failure (c-DMARD combination or addition of b-DMARDs) (40.0\% MTX-IR PsA patients achieved MDA after c-DMARD combination vs $64.7 \%$ MTX-IR PsA patients achieved MDA after b-DMARD addition, $p=0.32$; 44.4\% MTX-IR $\mathrm{Ab}^{\text {neg }}$ RA patients achieved MDA after c-DMARD combination vs $50.0 \%$ MTX-IR Ab ${ }^{\text {neg }}$ RA patients achieved MDA after b-DMARD addition, $p=0.78$ ).

\section{Discussion}

As in RA, synovial membrane inflammation plays a key pathogenetic role in PsA and many studies have focused on this topic in the last decades, especially looking for differential synovial tissue biomarkers between different 
Table $2 \Vdash H C$ features of PSA and Ab ${ }^{\text {neg }}$ RA cohorts based on the achievement of MDA and DAS remission after 6 months follow-up

\begin{tabular}{|c|c|c|c|c|c|c|}
\hline & \multicolumn{6}{|l|}{ PsA cohort } \\
\hline & \multicolumn{2}{|l|}{ Naive $(N=12)$} & \multirow[t]{2}{*}{$p$} & \multicolumn{2}{|l|}{ MTX-IR $(N=22)$} & \multirow[t]{2}{*}{$p^{1}$} \\
\hline & $\mathrm{MDA}(N=6)$ & No MDA $(N=6)$ & & $\operatorname{MDA}(N=9)$ & No MDA $(N=13)$ & \\
\hline Follicular synovitis, $n$ (\%) & $3(50.0)$ & $3(50.0)$ & 1.00 & $3(33.3)$ & $7(53.8)$ & 0.34 \\
\hline CD68 (L) (mean \pm SD) & $1.58 \pm 0.80$ & $2.42 \pm 0.73$ & 0.09 & $1.86 \pm 0.90$ & $2.0 \pm 1.07$ & 0.77 \\
\hline CD68 (SL) (mean \pm SD) & $1.25 \pm 1.08$ & $2.16 \pm 0.61$ & 0.13 & $1.77 \pm 0.93$ & $2.0 \pm 1.07$ & 0.54 \\
\hline CD21 (mean \pm SD) & $0.58 \pm 0.92$ & $0.92 \pm 1.02$ & 0.59 & $0.96 \pm 0.80$ & $0.33 \pm 0.43$ & 0.06 \\
\hline CD20 (mean \pm SD) & $0.83 \pm 0.82$ & $1.17 \pm 0.93$ & 0.56 & $1.19 \pm 0.83$ & $1.06 \pm 0.40$ & 0.64 \\
\hline CD3 $($ mean \pm SD) & $0.91 \pm 0.33$ & $1.99 \pm 0.84$ & 0.02 & $1.65 \pm 0.77$ & $2.11 \pm 0.96$ & 0.29 \\
\hline CD117 (mean \pm SD) & $1.16 \pm 0.82$ & $1.42 \pm 0.49$ & 0.62 & $1.12 \pm 0.62$ & $1.39 \pm 0.61$ & 0.32 \\
\hline CD138 (mean \pm SD) & $0.67 \pm 0.75$ & $1.25 \pm 0.88$ & 0.25 & $0.58 \pm 0.64$ & $0.61 \pm 0.60$ & 0.84 \\
\hline \multirow[t]{4}{*}{$\mathrm{CD} 31^{+}$vessels (mean $\left.\pm \mathrm{SD}\right)$} & $32.50 \pm 13.41$ & $40.75 \pm 6.84$ & 0.39 & $22.81 \pm 11.31$ & $25.21 \pm 13.06$ & 0.58 \\
\hline & \multicolumn{6}{|c|}{$A b^{\text {neg }} R A$ cohort } \\
\hline & \multicolumn{2}{|l|}{ Naive $(N=27)$} & \multirow[t]{2}{*}{$p^{2}$} & \multicolumn{2}{|l|}{ MTX-IR $(N=28)$} & $p^{3}$ \\
\hline & $\operatorname{REM}(N=11)$ & No REM $(N=16)$ & & $\operatorname{REM}(N=11)$ & No REM $(N=17)$ & \\
\hline Follicular synovitis, n (\%) & $6(46.2)$ & $6(42.6)$ & 0.86 & $3(27.3)$ & $7(41.2)$ & 0.45 \\
\hline CD68 (L) (mean \pm SD) & $1.86 \pm 0.82$ & $2.23 \pm 0.68$ & 0.27 & $2.10 \pm 0.51$ & $1.97 \pm 0.83$ & 0.82 \\
\hline CD68 (SL) (mean \pm SD) & $0.92 \pm 0.58$ & $2.13 \pm 0.55$ & $<0.001$ & $1.35 \pm 0.78$ & $1.46 \pm 0.76$ & 0.66 \\
\hline CD21 (mean \pm SD) & $0.39 \pm 0.74$ & $0.65 \pm 1.08$ & 0.79 & $0.54 \pm 0.79$ & $0.77 \pm 1.13$ & 0.78 \\
\hline CD20 (mean \pm SD) & $1.64 \pm 1.02$ & $1.23 \pm 0.78$ & 0.26 & $1.46 \pm 0.99$ & $1.44 \pm 0.83$ & 0.85 \\
\hline CD3 $($ mean \pm SD) & $1.57 \pm 0.95$ & $1.57 \pm 0.83$ & 0.98 & $1.59 \pm 0.89$ & $1.47 \pm 0.87$ & 0.49 \\
\hline CD117 (mean \pm SD) & $0.57 \pm 0.43$ & $0.62 \pm 0.46$ & 0.79 & $0.77 \pm 0.56$ & $0.56 \pm 0.43$ & 0.28 \\
\hline CD138 (mean \pm SD) & $1.54 \pm 0.99$ & $1.77 \pm 1.05$ & 0.55 & $1.36 \pm 1.07$ & $1.62 \pm 1.28$ & 0.47 \\
\hline $\mathrm{CD} 1^{+}$vessels $($mean $\pm \mathrm{SD})$ & $35.64 \pm 7.69$ & $34.64 \pm 6.89$ & 0.54 & $22.35 \pm 5.28$ & $21.88 \pm 5.78$ & 0.52 \\
\hline
\end{tabular}

Data presented in italics have $p<0.05$

PsA psoriatic arthritis, $A b$ autoantibody, RA rheumatoid arthritis, MDA Minimal Disease Activity, REM remission, DAS Disease Activity Score, $p$ naive PsA reaching MDA vs naive PsA not achieving MDA, $p^{1}$ MTX-IR PsA reaching MDA vs MTX-IR PsA not achieving MDA, $p^{2}$ naive $A B^{\text {neg }}$ RA reaching DAS remission vs naive AB ${ }^{\text {neg }}$ RA not achieving DAS remission, $p^{3}$ MTX-IR $A B^{\text {neg }}$ RA reaching DAS remission vs MTX-IR AB ${ }^{\text {neg }}$ RA not achieving DAS remission, $M T X-I R$ methotrexate inadequately responder

types of chronic inflammatory joint diseases. More recently, the new advances in collecting synovial tissue through minimally invasive techniques have provided insight into the pathogenetic mechanisms of such joint diseases and facilitate differential diagnosis, stratification prognosis, and identification of treatment effects and new therapeutic targets [13].

In our study, we investigated, for the first time, the synovial histological features of a selected cohort of PsA patients, with peripheral joint involvement, compared to ACPA/RF seronegative RA cohort stratified based on the disease phase (disease onset and after DMARD insufficient response respectively) finding differential histological features of synovial tissue inflammation composition and biomarkers of therapeutic response.

Both RA and PsA are systemic autoimmune diseases characterized by chronic inflammation of the joint which leads to the destruction of the cartilage and bone $[14,15]$. In particular, the clinical presentation of PsA is heterogeneous, variably involving the synovium of peripheral joints, spine, and/or entheses [6]. Moreover, PsA patients may develop articular structural damage both in terms of erosions and new bone formation and may also develop systemic complications including the development of metabolic syndrome and increased cardiovascular risk with concomitant reduced life expectancy [16, 17]. The synovium in PsA represents a primary target of disease pathogenesis, together with the skin and entheses, with a distinct gene signature compared to healthy and other joint diseases [18]. Thus, it is an intriguing and plausible site in exploring important mechanisms of the disease.

Multiple studies have characterized the histological features of synovitis in PsA compared with RA, proving that there are some substantial histological differences; notably, the PsA synovitis was shown to be characterized by less pronounced lining layer hyperplasia and fewer monocytes/macrophages than are seen in RA [19-21]. Given that it has already been clearly shown that oligoarticular and polyarticular PsA presents comparable histopathological characteristics [4], in PsA, there is a 
higher grade of synovial vascularization, with a different vascular pattern, characterized by immature, tortuous, and branched vessels, compared with the straight blood vessels more likely observed in RA [22].

Despite these advances, currently, there are no differential synovial tissue biomarkers between PsA and RA especially if the latter is diagnosed in a clinical setting of negativity for ACPA and RF antibodies. This particular setting may create difficulties in terms of differential diagnosis and prognosis in the earliest undifferentiated phase of the disease. To address this issue, we have previously demonstrated that synovial tissue analysis in terms of histological, ultrasound, and epigenetic signature may support the clinician in the identification of patients with ACPA/RF seronegative undifferentiated arthritis with high likelihood chance of clinical differentiation towards definite arthritis (PsA or RA) [23]. In particular, synovial tissue enriched with $\mathrm{CD}^{+} 8^{+}$and $\mathrm{CD}^{+}$cells and high $\mathrm{CD} 31^{+}$vessels characterized ACPA/ RF seronegative undifferentiated arthritis patients evolving into $\mathrm{Ab}^{\text {neg }} \mathrm{RA}$ or PsA [23].

Comparing PsA and $\mathrm{Ab}^{\text {neg }} \mathrm{RA}$, histological analysis of synovial tissue composition revealed similarities in lining and sublining $\mathrm{CD}_{6} 8^{+}$and sublining $\mathrm{CD} 21^{+}, \mathrm{CD} 20^{+}$, and $\mathrm{CD}^{+}$cell distribution. Previously, controversial data were reported about $\mathrm{CD}^{+}$cell distribution among PsA and RA. However, no study has been conducted selecting $\mathrm{Ab}^{\text {neg }} \mathrm{RA}$ patients only as the comparison group and multiple methods of synovial tissue collection were used (arthroscopic or needle biopsies vs tissue obtained during joint replacement surgery) [24-26]. Other inflammatory cells such as mast cells and plasma cells take part in the tissue inflammatory infiltrate in PsA and RA [27, 28]. In particular, $\mathrm{CD} 117^{+}$cells have been previously shown more likely in synovial tissue of SpA, including PsA, expressing significantly more interleukin-17 than in RA synovitis regardless of TNF inhibition [27]. In our cohort, synovial tissue of PsA patients was found to be enriched in CD117 cells in the sublining area compared to $A b^{\text {neg }} R A$ irrespective of the disease phase. Interestingly, $\mathrm{CD} 117^{+}$distribution was found more likely in the context of tissue lymphoid aggregates. Conversely, synovial tissue of $\mathrm{Ab}^{\text {neg }}$ RA patients was found to be enriched in $\mathrm{CD}_{138^{+}}$cells compared to PsA synovial tissue, underlining the crucial role of B lymphocytes in RA pathogenesis and suggesting the need to investigate additional autoantibody specificities despite ACPA/RF negativity in such patient category. Moreover, the detection of lympho-neogenesis is a frequent feature of PsA synovitis with the expression of peripheral lymph node addressin-positive high endothelial venules and CXCL13/CCL21 expression demonstrating that the microanatomical bases for germinal center formation are present in PsA synovial tissue [29]. In this context, the concept of the autoimmune nature of PsA disease is strengthened by the recent detection of autoantibodies against modified antigens in the peripheral blood and synovial tissue of early naive to treatment PsA patients [30].

Increased vascularity has been reported in both psoriatic skin lesions and synovial tissue in PsA. In the dermis of the psoriatic skin, an abundance of dilated and tortuous blood vessels is present [31]. Multiple authors have reported that PsA synovium is characterized by an increase in macroscopically tortuous blood vessels, and this is more pronounced in, but not exclusive to, PsA than it is in RA synovium $[20,32]$. In our study cohort, CD31 IHC revealed that the mean number of synovial $\mathrm{CD} 31^{+}$vessels does not differ among PsA and $\mathrm{Ab}^{\text {neg }} \mathrm{RA}$, suggesting that the microscopical level does not mirror the macroscopical view of synovial vasculature in PsA compared to RA once disease phase stratification is done.

The development of novel biomarkers of therapeutic response prediction is urgently needed for PsA and RA management. Previous studies have investigated the effect of histological markers of synovitis in PsA and RA mirroring the therapeutic response to conventional and biological DMARDs respectively [33-35]. In particular, Pontifex et al. proposed IHC score for sublining $\mathrm{CD}^{+}$ cells as a useful biomarker of treatment response in PsA, enrolling a PsA cohort treated with TNF inhibitor [36] without providing clear cut-off value to be used at treatment initiation in naive PsA patients. In our study cohorts, we found that naive to treatment PsA with high likelihood of MDA achievement after DMARD treatment was more likely characterized, at baseline, by IHC score for $\mathrm{CD}^{+}$cells $<1.25$ compared to PsA patients not achieving this clinical outcome. Conversely, validation studies in RA patients, regardless of the autoimmune profile, found that variation in IHC score of sublining $\mathrm{CD}^{+} 8^{+}$cells is a valuable synovial biomarker mirroring the treatment response to conventional and biological DMARDs (rituximab and TNF inhibitor) [37-39]. Interestingly, in our study, we confirmed these findings in a well-selected naive to treatment $A b^{\text {neg }} R A$ patient cohort in which $A b^{\text {neg }} \mathrm{RA}$ patients with high likelihood chance of DAS remission achievement after DMARD treatment were more likely characterized, at baseline, by IHC score for sublining $\mathrm{CD}^{+} 8^{+}$cells $<2.5$ compared to $\mathrm{Ab}^{\text {neg }} \mathrm{RA}$ patients not achieving DAS remission after DMARD treatment.

\section{Conclusions}

In conclusion, our comparative study assessing the histological features of synovial tissues obtained from naive to treatment and MTX-IR PsA and $A b^{\text {neg }}$ RA patients revealed that PsA synovitis is characterized by being mast cell $\left(\mathrm{CD} 117^{+}\right)$rich but plasma cell $\left(\mathrm{CD} 138^{+}\right)$ poor whereas $A b^{\text {neg }} \mathrm{RA}$ synovitis by the reverse findings, 
being plasma cell $\left(\mathrm{CD} 38^{+}\right)$rich but mast cell $\left(\mathrm{CD} 117^{+}\right)$ poor. These different histopathologic biomarkers may help to solve the diagnostic overlapping issue in the setting of ACPA/RF negativity at the disease onset. Moreover, baseline IHC scores of $\mathrm{CD}^{+}$and sublining $\mathrm{CD}^{+} 8^{+}$ arose as useful biomarkers of treatment response to first-line DMARDs in PsA and $\mathrm{Ab}^{\text {neg }} \mathrm{RA}$ respectively, suggesting the need to include both parameters in more extensive future synovial tissue biopsy-driven clinical trials for these inflammatory joint conditions.

\section{Additional files}

Additional file 1: Figure S1. (a-b) ROC curve analysis for cut-off values for $\mathrm{CD}^{+}$cells and $\mathrm{SLCD} 68^{+}$cells $\mathrm{HC}$ in naive PSA and $\mathrm{Ab}^{\text {neg }} \mathrm{RA}$ patients. $\mathrm{SL}$ sublining, PSA psoriatic arthritis, Ab autoantibody, RA rheumatoid arthritis, IHC immunohistochemistry. (TIF 12416 kb)

Additional file 2: Table S1. Inter-rater agreement coefficients for CD68, CD21, CD20, CD3, CD117, CD138, and CD31 IHC scores. (DOCX 12 kb)

\section{Abbreviations \\ $A b^{\text {neg: }}$ : Autoantibody negative; ACPA: Anti-citrullinated peptide antibody; CD: Cluster designation; CRP: C-reactive protein; DAPSA: Disease Activity in PSoriatic Arthritis; DAS: Disease Activity Score; ESR: Erythrocyte sedimentation rate; IHC: Immunohistochemistry; MDA: Minimal Disease Activity; MTX- IR: Methotrexate inadequately responder; PSA: Psoriatic arthritis; RA: Rheumatoid arthritis; REM: Remission; RF: Rheumatoid factor; SJC: Swollen joint count; TJC: Tender joint count}

\section{Acknowledgements}

Not applicable.

\section{Funding}

The authors received no specific funding for this work.

\section{Availability of data and materials}

The datasets generated and/or analyzed for the present study are available from the corresponding author on reasonable request.

\section{Authors' contributions}

$\mathrm{SA}, \mathrm{GF}$, and $\mathrm{EG}$ gave substantial contributions to the study conception and design. $\mathrm{SA}, \mathrm{DB}, \mathrm{BT}, \mathrm{LB}, \mathrm{LP}, \mathrm{MRG}, \mathrm{DoB}, \mathrm{ALF}, \mathrm{GP}$, and FF gave substantial contributions to the acquisition of data. SA, DB, BT, GF, and EG gave substantial contributions to the analysis and interpretation of data. $\mathrm{SA}, \mathrm{DB}$, $B T, L B, L P, M R G, D \circ B, A L F, G P, F F, G F$, and EG drafted the article and revised it critically for important intellectual content; $S A, D B, B T, L B, L P, M R G, D o B$, $A L F, G P, F F, G F$, and $E G$ gave final approval of the version of the article to be published.

\section{Ethics approval and consent to participate}

This study was conducted in accordance with the Declaration of Helsinki and was approved by the Ethics Committee of the Università Cattolica del Sacro Cuore (Protocol number: 6334/15). Signed informed consent was obtained from each patient included before any activity of the study was started.

\section{Consent for publication}

Not applicable.

\section{Competing interests}

The authors declare that they have no competing interests.

\section{Publisher's Note}

Springer Nature remains neutral with regard to jurisdictional claims in published maps and institutional affiliations.

\section{Author details}

'Division of Rheumatology, Fondazione Policlinico Universitario A. Gemelli IRCCS, Rome, Italy. ${ }^{2}$ Institute of Rheumatology, Università Cattolica del Sacro Cuore, Rome, Italy. ${ }^{3}$ Institute of Pathology, Fondazione Policlinico

Universitario A. Gemelli IRCCS, Rome, Italy. ${ }^{4}$ Institute of Pathology, Università Cattolica del Sacro Cuore, Rome, Italy.

Received: 24 February 2019 Accepted: 17 April 2019

Published online: 09 May 2019

\section{References}

1. Veale DJ, Fearon U. The pathogenesis of psoriatic arthritis. Lancet. 2018;391: 2273-84.

2. Shah K, Paris M, Mellars L, Changolkar A, Mease PJ. Real-world burden of comorbidities in US patients with psoriatic arthritis. RMD Open. 2017;3: e000588.

3. Najm A, Le Goff B, Orr C, Thurlings R, Cañete JD, Humby F, et al. Standardisation of synovial biopsy analyses in rheumatic diseases: a consensus of the EULAR Synovitis and OMERACT Synovial Tissue Biopsy Groups. Arthritis Res Ther. 2018;20:265.

4. Kruithof E, Baeten D, De Rycke L, Vandooren B, Foell D, Roth J, et al. Synovial histopathology of psoriatic arthritis, both oligo- and polyarticular, resembles spondyloarthropathy more than it does rheumatoid arthritis. Arthritis Res Ther. 2005:7:R569-8.

5. Veale DJ, Fearon U. What makes psoriatic and rheumatoid arthritis so different? RMD Open. 2015:1:e000025.

6. Taylor W, Gladman D, Helliwell P, Marchesoni A, Mease P, Mielants H, et al. Classification criteria for psoriatic arthritis. Development of new criteria from a large international study. Arthritis Rheumatol. 2006;54:2665-73.

7. Aletaha D, Neogi T, Silman AJ, Funovits J, Felson DT, Bingham CO III, et al. Rheumatoid arthritis classification criteria: an American College of Rheumatology/European League Against Rheumatism collaborative initiative. Ann Rheum Dis. 2010;69:1580-8.

8. Coates LC, Fransen J, Helliwell PS. Defining minimal disease activity in psoriatic arthritis: a proposed objective target for treatment. Ann Rheum Dis. 2010;69:48-53.

9. Felson DT, Smolen JS, Wells G, Zhang B, van Tuyl LH, Funovits J, et al. American College of Rheumatology/European League against Rheumatism provisional definition of remission in rheumatoid arthritis for clinical trials. Ann Rheum Dis. 2011;70:404-13.

10. Gossec L, Smolen JS, Ramiro S, de Wit M, Cutolo M, Dougados M, et al. European League Against Rheumatism (EULAR) recommendations for the management of psoriatic arthritis with pharmacological therapies: 2015 update. Ann Rheum Dis. 2016;75:499-510.

11. Smolen JS, Landewé R, Bijlsma J, Burmester G, Chatzidionysiou K, Dougados $M$, et al. EULAR recommendations for the management of rheumatoid arthritis with synthetic and biological disease-modifying antirheumatic drugs: 2016 update. Ann Rheum Dis. 2017;76:960-77.

12. Alivernini S, Tolusso B, Petricca L, Bui L, Di Sante G, Peluso G, et al. Synovial features of rheumatoid arthritis and psoriatic arthritis patients in clinical and ultrasound remission differ under anti-TNF therapy. A clue to interpret different chances of relapse after clinical remission? Ann Rheum Dis. 2017; 76:1228-36.

13. Orr C, Sousa E, Boyle DL, Buch MH, Buckley CD, Cañete JD, et al. Synovial tissue research: a state-of-the-art review. Nat Rev Rheumatol. 2017;13:463-75.

14. Smolen JS, Aletaha D, McInnes IB. Rheumatoid arthritis. Lancet. 2016;388: 2023-38.

15. Fitzgerald O, Winchester R. Psoriatic arthritis: from pathogenesis to therapy. Arthritis Res Ther. 2009;11:214.

16. Wong K, Gladman DD, Husted J, Long JA, Farewell VT. Mortality studies in psoriatic arthritis: results from a single outpatient clinic. I. Causes and risk of death. Arthritis Rheumatol. 1997:40:1868-72.

17. Gladman DD. Mortality in psoriatic arthritis. Clin Exp Rheumatol. 2008;26:S62-5.

18. Belasco J, Louie JS, Gulati N, Wei N, Nograles K, Fuentes-Duculan J, et al. Comparative genomic profiling of synovium versus skin lesions in psoriatic arthritis. Arthritis Rheumatol. 2015;67:934-44.

19. Veale D, Yanni G, Rogers S, Barnes L, Bresnihan B, Fitzgerald O. Reduced synovial membrane macrophage numbers, ELAM-1 expression, and lining layer hyperplasia in psoriatic arthritis as compared with rheumatoid arthritis. Arthritis Rheumatol. 1993;36:893-900. 
20. Reece RJ, Canete JD, Parsons WJ, Emery P, Veale DJ. Distinct vascular patterns of early synovitis in psoriatic, reactive, and rheumatoid arthritis. Arthritis Rheumatol. 1999;42:1481-4.

21. Baeten D, Demetter P, Cuvelier C, Van Den BF, Kruithof E, Van DN, et al. Comparative study of the synovial histology in rheumatoid arthritis, spondyloarthropathy, and osteoarthritis: influence of disease duration and activity. Ann Rheum Dis. 2000;59:945-53.

22. Moll C, Bogas M, Gómez-Puerta JA, Celis R, Vázquez I, Rodríguez F, et al. Macroscopic features of knee synovitis in early untreated Behçet disease and psoriatic arthritis. Clin Rheumatol. 2009;28:1053-7.

23. Alivernini S, Tolusso B, Petricca L, Bui L, Di Mario C, Gigante MR, et al. Synovial predictors of differentiation to definite arthritis in patients with seronegative undifferentiated peripheral inflammatory arthritis: microRNA signature, histological, and ultrasound features. Front Medicine. 2018;5:186.

24. van Kuijk AW, Reinders-Blankert P, Smeets TJ, Dijkmans BA, Tak PP. Detailed analysis of the cell infiltrate and the expression of mediators of synovial inflammation and joint destruction in the synovium of patients with psoriatic arthritis: implications for treatment. Ann Rheum Dis. 2006;65:1551-7.

25. Danning CL, Illei GG, Hitchon C, Greer MR, Boumpas DT, McInnes IB. Macrophage-derived cytokine and nuclear factor kappaB p65 expression in synovial membrane and skin of patients with psoriatic arthritis. Arthritis Rheumatol. 2000:43:1244-56.

26. Salvador G, Sanmarti R, Garcia-Peiro A, Rodriguez-Cros JR, Munoz-Gomez J, Canete JD. p53 expression in rheumatoid and psoriatic arthritis synovial tissue and association with joint damage. Ann Rheum Dis. 2005;64:183-7.

27. Noordenbos T, Yeremenko N, Gofita I, van de Sande M, Tak PP, Caňete JD, et al. Interleukin-17-positive mast cells contribute to synovial inflammation in spondylarthritis. Arthritis Rheumatol. 2012;64:99-109.

28. Rivellese F, Mauro D, Nerviani A, Pagani S, Fossati-Jimack L, Messemaker T, et al. Mast cells in early rheumatoid arthritis associate with disease severity and support B cell autoantibody production. Ann Rheum Dis. 2018;77:1773-81.

29. Cañete JD, Santiago B, Cantaert T, Sanmartí R, Palacin A, Celis R, et al. Ectopic lymphoid neogenesis in psoriatic arthritis. Ann Rheum Dis. 2007;66:720-6.

30. Frasca L, Palazzo R, Chimenti MS, Alivernini S, Tolusso B, Bui L, et al. AntiLL37 antibodies are present in psoriatic arthritis (PSA) patients: new biomarkers in PsA. Front Immunol. 2018;12(9):1936.

31. Braverman IM, Yen A. Ultrastructure of the capillary loops in the dermal papillae of psoriasis. J Invest Dermatol. 1977;68:53-60.

32. Canete JD, Rodriguez JR, Salvador G, Gomez-Centeno A, Munoz-Gomez J, Sanmarti R. Diagnostic usefulness of synovial vascular morphology in chronic arthritis. A systematic survey of 100 cases. Semin Arthritis Rheum. 2003:32:378-87.

33. Kane D, Gogarty M, O'Leary J, Silva I, Bermingham N, Bresnihan B, et al. Reduction of synovial sublining layer inflammation and proinflammatory cytokine expression in psoriatic arthritis treated with methotrexate. Arthritis Rheumatol. 2004;50:3286-95.

34. Goedkoop AY, Kraan MC, Teunissen MB, Picavet DI, de Rie MA, Bos JD, et al. Early effects of tumour necrosis factor alpha blockade on skin and synovial tissue in patients with active psoriasis and psoriatic arthritis. Ann Rheum Dis. 2004:63:769-73.

35. Canete JD, Pablos JL, Sanmarti R, Mallofre C, Marsal S, Maymo J, et al. Antiangiogenic effects of anti-tumor necrosis factor alpha therapy with infliximab in psoriatic arthritis. Arthritis Rheum. 2004;50:1636-41.

36. Pontifex EK, Gerlag DM, Gogarty M, Vinkenoog M, Gibbs A, Burgman I, et al. Change in CD3 positive T-cell expression in psoriatic arthritis synovium correlates with change in DAS28 and magnetic resonance imaging synovitis scores following initiation of biologic therapy--a single centre, open-label study. Arthritis Res Ther. 2011;13:R7.

37. Humby F, Kelly S, Hands R, Rocher V, DiCicco M, Ng N, et al. Use of ultrasound-guided small joint biopsy to evaluate the histopathologic response to rheumatoid arthritis therapy: recommendations for application to clinical trials. Arthritis Rheumatol. 2015;67:2601-10.

38. Bresnihan B, Pontifex E, Thurlings RM, Vinkenoog M, El-Gabalawy H, Fearon $\mathrm{U}$, et al. Synovial tissue sublining CD68 expression is a biomarker of therapeutic response in rheumatoid arthritis clinical trials: consistency across centers. J Rheumatol. 2009:36:1800-2.

39. Haringman JJ, Gerlag DM, Zwinderman AH, Smeets TJ, Kraan MC, Baeten D, et al. Synovial tissue macrophages: a sensitive biomarker for response to treatment in patients with rheumatoid arthritis. Ann Rheum Dis. 2005;64: 834-8.

\section{Ready to submit your research? Choose BMC and benefit from:}

- fast, convenient online submission

- thorough peer review by experienced researchers in your field

- rapid publication on acceptance

- support for research data, including large and complex data types

- gold Open Access which fosters wider collaboration and increased citations

- maximum visibility for your research: over $100 \mathrm{M}$ website views per year

At BMC, research is always in progress.

Learn more biomedcentral.com/submissions 